NBER WORKING PAPER SERIES

COASEAN BARGAINING TO ADDRESS ENVIRONMENTAL EXTERNALITIES

Gary D. Libecap

Working Paper 21903

http://www.nber.org/papers/w21903

\author{
NATIONAL BUREAU OF ECONOMIC RESEARCH \\ 1050 Massachusetts Avenue \\ Cambridge, MA 02138 \\ January 2016
}

Very helpful comments were provided by Eric Edwards, Timothy Fitzgerald, Levi Marks, Claude Menard, Chris Pinchiff, and Lauren Steely. The views expressed herein are those of the author and do not necessarily reflect the views of the National Bureau of Economic Research.

NBER working papers are circulated for discussion and comment purposes. They have not been peerreviewed or been subject to the review by the NBER Board of Directors that accompanies official NBER publications.

(C) 2016 by Gary D. Libecap. All rights reserved. Short sections of text, not to exceed two paragraphs, may be quoted without explicit permission provided that full credit, including $(\mathbb{C}$ notice, is given to the source. 
Coasean Bargaining to Address Environmental Externalities

Gary D. Libecap

NBER Working Paper No. 21903

January 2016

JEL No. H23,K32,N5,Q28,Q38,Q58

\begin{abstract}
$\underline{\text { ABSTRACT }}$
I examine Ronald Coase's criticism of standard regulatory and tax policies to address environmental externalities. I elaborate some of Coase's key points and discuss opportunities for Coasean exchange as an alternative mitigation approach. Regulation, tax, and Coasean exchange, such as through cap-and-trade regimes, are presented as substitutes, based on the relative transaction costs involved. Transaction costs are those of information, bounding, enforcing, and exchanging property rights. In general, transaction costs are not examined in depth in the environmental economics literature. This is particularly the case for the costs of political bargaining and lobbying that arise from implementing and administering government regulation and tax policies, although these costs have received somewhat more attention with cap and trade regimes. Coasean exchange and important market design issues are illustrated with examples.
\end{abstract}

Gary D. Libecap

Bren School of Environmental Science

and Management and Economics Department

University of California, Santa Barbara

Bren Hall 4412

Santa Barbara, CA 93106-5131

and NBER

glibecap@bren.ucsb.edu 


\title{
Coasean Bargaining to Address Environmental Externalities
}

\author{
Gary D. Libecap ${ }^{1}$
}

I examine Ronald Coase's criticism of standard regulatory and tax policies to address environmental externalities. I elaborate some of Coase's key points and discuss opportunities for Coasean exchange as an alternative mitigation approach. Regulation, tax, and Coasean exchange, such as through cap-and-trade regimes, are presented as substitutes, based on the relative transaction costs involved. Transaction costs are those of information, bounding, enforcing, and exchanging property rights. In general, transaction costs are not examined in depth in the environmental economics literature. This is particularly the case for the costs of political bargaining and lobbying that arise from implementing and administering government regulation and tax policies, although these costs have received somewhat more attention with cap and trade regimes. Coasean exchange and important market design issues are illustrated with examples.

\section{Coase and the Environment}

The iconic examples used by Ronald Coase to illustrate The Problem of Social Cost were environmental ones: noise pollution generated by a confectioner and inflicted on the neighboring doctor, a rancher's straying cattle that grazed upon a farmer's fields, air pollution from a factory that stained the laundry of a nearby weaver, smoke from a home's fire place drifting across a neighborhood, the blockage of air flows by a home owner to a local public house that required ventilation to brew ale, and sparks from a railroad that ignited fires along its tracks. ${ }^{2}$ Coase was concerned about the ways in which such problems, commonly referred to as externalities were addressed in economics. Traditionally, the notion is that when private costs are less than social costs in economic decisions a distortion or market failure occurs, and government regulation or taxes are warranted as a correction. ${ }^{3}$ Coase's criticism was that in calling for such intervention economists implicitly assigned a property right that had not existed previously. For example, in restraining the rancher the policy granted a right to the farmer to be free of straying cattle or in restricting the factory the weaver/laundry owner was implicitly given a right to be free of air pollution. Coase argued that the property right was arbitrarily assigned and that this assignment, as well as the regulation or tax policy associated with it, might not maximize economic welfare.

Coase made two critiques of the traditional view of regulation, which often defaulted to a standard where the polluter pays. ${ }^{4}$ One was that traditional regulation ignores the reciprocal nature of the environmental problem, and the second was that the proper selection of the welfaremaximizing remedy, which could be to simply do nothing, requires an analysis of the comparative transaction costs - including the costs of lobbying and administering taxes and

\footnotetext{
${ }^{1}$ Professor, Bren School of Environmental Science and Management and Economics Department University of California, Santa Barbara and Research Associate, National Bureau of Economic Research. Very helpful comments were provided by Eric Edwards, Timothy Fitzgerald, Levi Marks, Claude Menard, Chris Pinchiff, and Lauren Steely.

${ }^{2}$ Coase (1960). See also elaboration on some key issues in Coase (1992). Medema $(2011,2014)$ describes the origins of the Coase Theorem as well as its interpretation.

${ }^{3}$ The classic discussions are in Pigou (1932), Scitovsky (1954), and Samuelson (1948, 208).

${ }^{4}$ Regulation and taxes are discussed interchangeably here, although there can be important differences (Weitzman 1974).
} 
regulations. Either the rancher or the farmer, the laundry owner or the factory owner, was inflicting costs on the other. For instance, the farmer and the laundry owner who benefited from traditional regulation were limiting productive inputs available to the rancher (land) and the factory owner (air for waste disposal) without a clear property right to do so. As Coase (1960, 44) described: "If factors of production are thought of as rights, it becomes easier to understand that the right to do something which has a harmful effect ... is also a factor of production. ... The cost of exercising a right (of using a factor of production) is always the loss which is suffered elsewhere in consequence of the exercise of that right ... the inability to cross land, to park a car, to build a house, to enjoy a view, to have peace and quiet or to breathe clean air." 5 Coase argued that when the reciprocal nature of the problem is recognized and there are no inherent property rights, the assignment of the rights should be based on the opportunity costs involved to maximize the value of overall economic production. Coase stated $(1960,34)$ "When an economist is comparing alternative social arrangements, the proper procedure is to compare the total social product yielded by those different arrangements." The traditional assignment of a property right in a policy, such as in the polluter pays principle, could make society worse off.

Alternatively, Coase envisioned a bargaining setting, whereby the polluter and the pollutee negotiated over the amount of pollution to be released with a corresponding exchange of payments. This arrangement necessarily also required the granting of an initial property right either to clean air or to pollute, but Coase was agnostic about the assignment of the rights so long as transaction costs were low enough for trade. With trade, rather than regulation or taxes, an efficient solution that maximized social product could result. While the initial assignment of property rights had distributional implications because the polluter would have to pay the pollutee or vice versa, the allocation that maximized total wealth was arrived at in either case. The assertion that the efficient outcome will result regardless of the allocation of rights has been termed the Coase Theorem (Medema 2011). The theorem's practical relevance is often questioned because the assumption of low transaction costs is not supported in many important environmental and natural resource settings. Indeed, Coase recognized that transaction costs could be high when he noted $(1960,39)$ : "The reason why some activities are not the subject of contracts is exactly the same as the reason why some contracts are commonly unsatisfactory - it would cost too much to put the matter right." Coase suggested that because transaction costs permeate all remedies to the problem of social cost, the welfare-maximizing response would be to compare the alternative costs and benefits of three solutions: defining property rights so as to facilitate exchange, designing and implementing a corrective tax, or regulating production.

With this in mind, Coase called for economists to shift attention from simply identifying market failure to examining why environmental markets were missing in the first place and what might be done to promote them. Coase implicitly asked for consideration of the types of institutions that could lower the costs of defining and enforcing informal and formal property rights. Markets based on these property rights could lead to exchange as a means of mitigating externalities. When environmental problems are recognized as reciprocal, the direction of causality can only be determined when rights are assigned. Once property rights are defined, the number of claimants for environmental or resource assets is constrained, potential trading partners are identified, and market exchange becomes feasible. Property rights instil incentives

5 This passage is quoted in Anderson and Libecap $(2014,68)$. They also summarize the key points made by Coase (2014, 53-91). 
for conservation and investment by directing the associated flows of benefits and costs to rights holders. Through exchange, information is generated about the opportunity costs of alternative uses, and resource users can respond to changing resource values and technologies. By contrast, when rights are not defined, claimants can be virtually unlimited and rents are dissipated by open access as outlined by Gordon (1954) and described by Hardin (1968) as The Tragedy of the Commons. Moreover, trade is not possible because there are no recognized parties for any transaction. This is a standard externality setting, and Coase suggested that the most direct solution to the externality may be to define or recognize existing informal property rights and to promote environmental markets, rather than to resort to regulation or tax policies and the implicit assignment of rights that they designate (Libecap 2008). These issues receive most of Coase's attention in The Problem of Social Cost, but the role of transaction costs in shaping regulation, tax policies, and Coasean exchange deserves more attention. This is the focus of the rest of the paper.

\section{Transaction Costs of Government Regulation and Taxes}

When transaction costs are considered, government intervention may not be well suited to address environmental and resource problems. For example, consider the government's cost of obtaining information from industry. While trades within a market generate information about compliance costs and alternative resource values, politicians and bureaucratic officials often do not have such information for designing optimal tax rates or regulatory restrictions. They generally must rely upon information provided by competing interest groups (industry, environmental) and the completeness of the data provided depends upon interest group competition and how well the groups reflect the broad interests of society. With very incomplete information, taxes may be too high or too low, leading to the continued imposition of social costs. Further, regulation may be too strict or too lenient or provide competitive advantages to the most effective lobby groups. ${ }^{6}$ Moreover, because users are taxed or regulated by government policy, they have an incentive to seek less-constrained margins for evasion, resulting in social losses.

In addition to limited information on opportunity costs that constrain policy, neither politicians nor bureaucratic officials bear the costs of their actions in the way that market traders do. This is critical because their decisions carry the power of the state, unlike those made by private parties. Politicians and bureaucratic officials generally do not have property rights to the resource, and are not typically the direct residual claimants to added rents generated from market exchange or to the costs imposed by taxes or regulation. Accordingly, government policy makers can make decisions that generate social losses, in the same way as do the decisions of private parties when private and social costs differ.

As a result, it is unclear that government decision makers are motivated to maximize aggregate economic welfare in their actions. As with the factory owner, the railroad owner and the rancher, the decisions of politicians and bureaucratic officials inflict external costs (or benefits) on others because they do not necessarily weigh all social costs (or benefits) in their

\footnotetext{
${ }^{6}$ For discussion of information distortion in the political process that shifts lobby influence see Johnson and Libecap (2001) and Edwards, Cristi, Edwards and Libecap (2016).
} 
actions. ${ }^{7}$ Indeed, a competing hypothesis is that their actions are the result of lobby activity by self-interested, narrow constituent groups as described by Buchanan and Tullock (1962), Peltzman (1976), Becker (1983), and Laffont and Tirole (1991). In this case, the most politicallyinfluential interest groups dominate, capturing policy benefits and spreading costs to general citizens. Further, because governments do not typically face active competition, their policies can become entrenched as constituencies develop expectations about benefit flows and lobby to block policy adjustments. In that setting, politicians and agency officials may have little ability to modify regulatory and tax policies or to reallocate resources as external conditions change. By contrast market exchange is particularly adept at such adjustments because unlike politicians, traders are residual claimants to the net benefits of responding to new conditions. Market traders are more able to arbitrage flexibly across both options and time than are politicians or bureaucratic officials.

Competition among many interest groups and politicians, as well as political control over the bureaucracy, may mitigate the potential social losses that can arise from regulation or taxes (Becker 1983; Aidt 2003). ${ }^{8}$ The formation of interest groups, lobbying, political competition, and sufficient oversight of bureaucracies, however, involve transaction costs just as is the case with defining private property rights and engaging in Coasean trades (Krutilla and Krause 2010). Accordingly, one cannot a priori conclude that the options described by Coase are not relevant because of high transaction costs, without considering the costs of the alternatives. The costs of defining and trading environmental and resource property rights may be high, but they are not necessarily higher than for political intervention via regulation and taxes.

\section{Transaction Costs of Environmental Exchange when Resources are Excludable}

Coase $(1960,15)$ defined the transaction costs associated with trade in the following manner: "In order to undertake a market transaction it is necessary to discover who it is that one wishes to deal with, to inform people that one wishes to deal and on what terms, to conduct negotiations leading up to a bargain, to draw up the contract, to undertake the inspection needed to make sure that the terms of the contract are being observed and so on."

In considering the transaction costs of defining property rights and engaging in Coasean exchange, it is useful to think of resources as existing in a transaction-costs continuum. The greatest potential for Coasean exchange involves excludable resources found at one end of the continuum, where property rights can be designated and traded at lower costs than more nonexcludable resources found further along the continuum.

What factors affect transaction costs along the continuum? One factor is resource value. As argued by Demsetz (1967), more valuable resources offer greater rents from externality mitigation through the definition of property rights, and also invite greater competition that dissipates those rents. Thus there are greater benefits to establishing property rights and greater losses when those rights do not exist, both of which may raise transaction costs. Another factor is the physical characteristics of the resource that determine excludability. Resources that are

\footnotetext{
${ }^{7}$ Bureaucratic incentives are examined in Johnson and Libecap (1994, 154-76).

${ }^{8}$ Conditions impairing political completion, however, are described by Johnson and Libecap (2001) and stability and potential inflexibility in government programs are examined by Johnson and Libecap (2003).
} 
stationary, observable, smaller, and have stable quality distributions have lower costs of measurement, enforcement, and exchange. Land has these characteristics, which is why land and environmental resources tied to it have the greatest potential for Coasean trade. A third factor is the characteristics of the parties. When the parties involved are homogeneous in production and search costs, communicate often, understand the resource, and have similar objectives for its conservation or protection, agreement on the assignment of property rights can occur at lower costs. These resource and user characteristics are similar to those outlined by Ostrom $(1990,90)$ and by Cox et al (2010, Table 4) for successful small-scale community management of commonpool or open-access resources.

The allocation of rights can have important distributional implications affecting transaction costs. Some parties may resist the assignment of formal property rights and subsequent actions taken to alleviate the externality, even if there are aggregate net social gains from doing so. For example, those who have adapted well to open access may earn inframarginal rents, whereas others receive low or zero rents as predicted by Gordon (1954). These latter parties have a particular incentive to assign property rights to reduce open-access losses from excessive production or use of the resource, but these actions may make the former worse off unless their advantages are recognized in the property rights assignment (Leonard and Libecap 2015). Distributional conflicts raise transaction costs and can block, delay, or seriously modify the rights that are defined, leaving many avenues open for continued rent dissipation. Moreover, the rights allocation can affect subsequent transaction costs if, for example, they are assigned in a non-uniform way that makes trading more difficult or if they are granted to communities or groups where group decision making is costly. ${ }^{9}$

Examples of successful Coasean exchange to constrain overexploitation of valuable resources include the emergence of formal mineral rights in the $19^{\text {th }}$ century western U.S. and informal claims to lobster grounds in $20^{\text {th }}$ century Maine (Acheson 1975; Libecap 1978, 2009). More contemporary examples include conservation easements, land trusts, tradable development rights (TDRs), conservation banking, habitat credits, and instream flow rights. In these cases, landowners voluntarily limit land or water use in order to provide environmental amenities in exchange for reduced taxes, revenue from the sale of credits to protect open space or habitat, and revenue from the lease or sale of water rights for stream flow maintenance (Anderson and Libecap 2014, 113-4, 135-9, 144-53). Transaction costs are low because the resource is tied to land, which is boundable and excludable. The trades also can be consistent with a beneficiary pays principle whereby parties that benefit from reductions in resource exploitation compensate those who make the cut backs. Such arrangements are incentive compatible because costs and benefits are distributed proportionately. By contrast, direct land use controls and zoning rules are more often polluter-pays restrictions that create differential incentives for compliance among the regulated and hence raise the transaction costs of mitigation.10 Those that cut back bear costs and may receive no benefits from doing so.

\footnotetext{
${ }^{9}$ See Libecap and Lueck (2011), Libecap, Lueck, and O'Grady (2012), and O'Grady (2015) for analysis of the role of the standardized rectangular survey of land in North America, Australia, New Zealand and in Manhattan for lowering the transaction costs of property rights definition, enforcement and exchange.

${ }^{10}$ Cox et al (2010, Table 4) include a proportionate distribution of costs and benefits as a key condition for successful collective action.
} 
Coasean exchange is less feasible for resources further along the transaction costs continuum where exclusion costs are inherently higher. In these cases, defining property rights to the resource itself is too costly, but alternative exchange arrangements have been implemented. Below, I examine some selected cases that reveal the important market design considerations that affect transaction costs and market performance.

\section{Transaction Costs of Coasean Exchange when Resources are Non-Excludable}

Cap and trade is one option for non-excludable resources. The cap constrains total exploitation of the resource to a more efficient level compared to open-access, and limited use rights create scarcity and define who has access. Trading use rights allows for reduction in the number of parties using the resource or for equalizing compliance costs. For example, in fisheries the total annual allowable catch (TAC) can be distributed among fishers as transferable catch shares, and shareholders capture rents saved by reducing the harvest and the number of vessels and crews devoted to it. Under cap and trade, the TAC can be adjusted in order to protect fish stocks. This Coasean innovation was outlined first by Christy (1973) and put into place in varying ways by the 1990s in Iceland, New Zealand, Canada, the U.S. and elsewhere. Grafton et al (2000) and Costello et al (2008) document important gains. Cap and trade, especially when the shares are grandfathered, distributes costs and benefits proportionately, as in a beneficiarypays sharing rule, whereas traditional limited-entry regulation and related fishery input controls typically assign direct costs to regulated fishers, with any resulting benefits of harvest reductions spread broadly. The traditional implicit sharing rule, which is polluter pays, provides few incentives for fishers to comply in meeting the conservation objective.

Similarly, cap and trade in air pollution emission controls was suggested by Crocker (1966) and Dales (1968) and gradually implemented in the U.S. and elsewhere by the 1990s (Libecap 2008). Total allowable annual emissions are fixed and emission permits or allowances are distributed among regulated units. The cap can be gradually tightened to meet aggregate air quality goals. Permit owners can exchange permits for pollution emitted at a prescribed exchange rate, or reduce pollution and bank or trade unused permits. These parties arbitrage mitigation decisions against the costs of securing more permits. The parties with low costs of mitigation cut back more, while those with higher costs buy released permits. Ultimately in a competitive permit market the permit price equals the marginal cost of mitigation across all parties.

An advantage of cap and trade relative to regulation or taxes is that an aggregate target can be set without information as to how each party will respond. Prescriptive technology standards or other more disaggregate regulations are not required because the parties have incentive to select the low-cost means of responding to the cap, potentially reducing overall mitigation costs as compared to those under regulation. Further, parties have incentive to monitor compliance, lowering enforcement costs because they share in the gains of a viable trading market. Stavins (1995) describes in general terms the transaction costs associated with cap and trade in emission controls and Böhringer (2014) discusses those associated with the European Union Emission Trading Scheme (EU ETS).

Experiences with cap and trade in fisheries and emission permits, however, indicate that outcomes are very sensitive to market design. The key issue of concern here is the nature of the 
property right assigned because of its centrality for both Coasean exchange and internalizing social costs. Because use rights are created by government officials as portions of a cap, policy makers may limit the privileges provided to participants, including the term of the right, renewability, its tradability, banking, use as collateral, and compensation if other regulatory policies undermine use right value. Although these actions provide politicians and agency officials with greater control and flexibility (Stavins 2007, 30-2), they weaken property rights and the benefits of Coasean trades for mitigating externalities (Merrill and Smith 2010, 1-13).

To illustrate potential problems that arise in Coasean markets with weak property rights, consider fisheries. Despite the documented success of catch shares (Costello et al 2008), their full advantages are likely not being achieved due to insecure rights and restrictions on exchange. In the U.S. catch shares are use rights, which are explicitly not formal property rights, and are revocable without compensation by the state. Grainger and Costello (2014) compare dividend price ratios (lease price/sales price) and find that the ratios are significantly higher in the U.S., where sales are riskier than short-term leases due to the threat of revocation, than in New Zealand where catch shares are protected property rights. Trading of catch shares also is seriously constrained in the U.S. in order to limit fleet consolidation, which protects influential constituencies, such as small fish processors and remote fishing communities (Singh, Weninger and Doyle 2006). By contrast in New Zealand where shares trade freely there is a robust market (Newell, Sanchirico, and Kerr 2005).

Next, consider $\mathrm{SO}_{2}$ cap and trade. This ambitious national emission-permit trading scheme was put into place in the U.S. in 1990 to control $\mathrm{SO}_{2}$ following the high costs of centralized regulation. A total annual cap on aggregate $\mathrm{SO}_{2}$ emissions was set and gradually tightened and shares in the cap as emission permits were distributed among electric utilities. This was the first large-scale U.S. environmental program to rely on tradable emission permits, and it provided a precedent for their use in other cases (Anderson and Libecap 2014, 159-67). Electric utilities were required to surrender allowances for $\mathrm{SO}_{2}$ emissions and they could transfer or bank them for use in future years so as to equalize the marginal cost of compliance to the permit price. As Coase implied would be the case, the cap-and-trade program brought substantial declines in power plant $\mathrm{SO}_{2}$ releases at lower cost than under regulation. It has been estimated that abatement costs would have been more than three times as high under regulation to achieve the same level of pollution reduction (Keohane 2007). The 1990 law, however, also made pollution allowances revocable or adjustable without compensation by the regulatory agency. In 2005, agency officials began to use their discretion to differentially control emissions in certain states where there were serious downwind particulate releases. This action and related court challenges, however, undermined the national $\mathrm{SO}_{2}$ allowance trading market. It ultimately collapsed. Permits that had been purchased and banked by utilities could no longer be used. Some 12 million permits were stranded, dramatically losing value, with uncompensated losses estimated at $\$ 3$ billion (Fraas and Richardson 2010, 37, 43).

Other emission trading schemes also appear to have limited success in raising permit prices to estimated social costs. The EU ETS has been in operation since 2005 to control greenhouse gas (GHG) emissions, but after the initial phase of trading, emission permit prices generally have trended down and currently are at $\$ 8.57 /$ ton; the Regional Greenhouse Gas Initiative (RGGI) of 9 north-eastern U.S. states that started in 2009 has permit prices of $\$ 5.21 /$ ton; and the nascent California AB 32 carbon allowance 
trading system which began in 2011 has prices of $\$ 11.86-\$ 12.10 /$ ton. ${ }^{11}$ All are well below the estimated social cost of carbon of about $\$ 40 /$ ton. $^{12}$ Transaction costs associated with agreement on the cap and its reduction, the allocation of permits, enforcement, and the use of auction funds to subsidize competing renewable energy sources that undermine permit values (Böhringer 2014) all help explain these price patterns. Insecure property rights, trading restrictions (in the case of fisheries), and subsidized competing instruments (in the case of emissions control) lower the benefits of share ownership in cap and trade and its ability the address losses of open access more efficiently than regulation or tax policies.

\section{Transaction Costs and Coasean Trades for Global Externalities}

Along the transaction costs continuum, the costs of Coasean exchange are the highest for very broad-scale environmental externalities. Property rights in very expansive environmental settings do not exist, which means the parties cannot directly engage in Coasean trade. Because of narrow government jurisdictions, unilateral national or regional cap and trade alone is insufficient to address the global externality. As an alternative, a multinational agreement among national politicians for international mitigation theoretically could constrain use by countries in a coordinated fashion. Because mitigation values and costs differ within and across national constituencies, international environmental agreements assign different and uncertain long-term streams of benefits and costs. These can be viewed as policy-induced property rights with critical distributional implications, and the transaction costs of agreeing upon and enforcing them are extremely high (Libecap 2014). This explains why international environmental agreements, such as those to protect highly-migratory ocean fish stocks and to reduce GHG releases, have proved so elusive. When cross-national environmental agreements are achieved, the transaction costs of Coasean cap and trade within them, however, may not necessarily be greater than those encountered in coordinated international tax or regulatory policies.

\section{Final Remarks}

Coase identified a key alternative to traditional regulation and taxation for addressing environmental externalities: the definition and enforcement of property rights and reliance upon voluntary Coasean exchange. With a more expansive array of policy options, promoting conservation and environmental quality requires a comparison of transaction costs across all options. Coasean exchange will be appropriate in some settings and less so in others, depending on the nature of the resource and the users. Coase called for comparative institutional analysis to maximize welfare. As he cautioned, at any point in time, some environmental and natural resource open-access losses will be addressed in some manner, whereas others will not be. Transaction costs determine why this is the case. Policies that do not consider transaction costs will not result in Pareto improvements, even if mitigation of the externality occurs.

\footnotetext{
${ }^{11}$ EU ETS January 14, 2015; exchange rate of 1 euro $=\$ 1.1788$. EU ETS trading prices at http://www.investing.com/commodities/carbon-emissions-historical-data; RGGI http://www.rggi.org/ December 5, 2014; November 2014 AB 32 http://www.arb.ca.gov/cc/capandtrade/auction/results_summary.pdf

${ }^{12}$ http://www.epa.gov/climatechange/EPAactivities/economics/scc.html.
} 


\section{References}

James M. Acheson (1975) "The Lobster Fiefs: Economic and Ecological Effects of Territoriality in the Maine Lobster Industry." Human Ecology 3: 183-207.

Aidt, T.S. (2003), "Redistribution and Deadweight Cost: The Role of Political Competition," European Journal of Political Economy 19(2): 205-26.

Anderson, Terry L. and Gary D. Libecap (2014), Environmental Markets: A Property Rights Approach, New York: Cambridge University Press.

Becker, Gary S. (1983), “A Theory of Competition among Pressure Groups for Political Influence,” Quarterly Journal of Economics 98(3): 371-400.

Böhringer, Christoph (2014), "Two Decades of European Climate Policy: A Critical Appraisal," Review of Environmental Economics and Policy 8(1): 1-17.

Buchanan, James M. and Gordon Tullock, (1962), The Calculus of Consent, Ann Arbor: University of Michigan Press.

Christy, Francis T. Jr. (1973), "Fisherman Quotas: A Tentative Suggestion for Domestic Management," Occasional Paper \#19, Kingston, Rhode Island: Law of the Sea Institute, University of Rhode Island.

Coase, Ronald (1960), “The Problem of Social Cost," Journal of Law and Economics 3: 1-44.

Coase, Ronald (1992), "The Institutional Structure of Production", American Economic Review 82 (4): 713-719.

Costello, Christopher J., Steven D. Gaines, and John Lynham (2008), "Can Catch Shares Prevent Fisheries Collapse?". Science 321 (5896): 1678-1681.

Cox, Michael, Gwen Arnold, and Sergio Villamayor Tomás (2010), "A Review of Design Principles for Community-Based Natural Resource Management," Ecology and Society 15(4): 38-52.

Crocker, Thomas D. (1966), "The Structuring of Atmospheric Pollution Control Systems," in Harold Wolozin ed, The Economics of Air Pollution: A Symposium, New York: W.W. Norton.

Dales, John H. (1968), Pollution, Property and Prices, Toronto: University of Toronto Press.

Demsetz, Harold (1967), "Toward a Theory of Property Rights," American Economic Review 57(2): 347-59.

Edwards, Eric C., Oscar Cristi, Gonzalo Edwards, and Gary D. Libecap (2016), "An Illiquid Market in the Desert: The Role of Interest Groups in Shaping Environmental Policy," NBER working paper, 21869 
Fraas, Arthur G. and Nathan Richardson (2010), "Banking on Allowances: The EPA's Mixed Record in Managing Emissions-Market Transitions," Discussion Paper 10-42, Washington D.C.: Resources for the Future.

Gordon, H. Scott (1954), "The Economic Theory of a Common-Property Resource: The Fishery." Journal of Political Economy 62(2): 124-42.

Grafton, R. Quentin, Dale Squires, and Kevin J. Fox. (2000), "Private Property and Economic Efficiency: A Study of a Common-Pool Resource." Journal of Law and Economics 43 (2): 679-713.

Grainger, Corbett A. and Christopher J. Costello (2014), "Capitalizing Property Rights Insecurity in Natural Resource Assets." Journal of Environmental Economics and Management 67: 224-40.

Hardin, Garrett (1968), “The Tragedy of the Commons.” Science 162: 1243-48.

Johnson, Ronald N. and Gary D. Libecap (1994), The Federal Civil Service and the Problem of Bureaucracy: The Economics and Politics of Institutional Change, Chicago: University of Chicago Press and NBER.

Johnson, Ronald N. and Gary D. Libecap (2001), "Information Distortion and Competitive Remedies in Government Transfer Programs: The Case of Ethanol," Economics of Governance 2: 101-34.

Johnson, Ronald N. and Gary D. Libecap (2003), "Transaction Costs and Coalition Stability under Majority Rule,” Economic Inquiry 41(2): 193-207.

Keohane, Nathaniel O. (2007), "Cost Savings from Allowance Trading in the 1990 Clean Air Act: Estimates from a Choice Based Model," in Jody Freeman and Charles D. Kolstad, eds., Moving to Markets in Environmental Regulation: Lessons from Twenty Years of Experience, New York: Oxford University Press, 194-229.

Krutilla, Kerry and Rachel Krause (2010), "Transaction Costs and Environmental Policy: An Assessment Framework and Literature Review." International Review of Environmental and Resource Economics 4: 261-354.

Laffont, Jean J. and Jean Tirole (1991), "The Politics of Government Decision Making. A Theory of Regulatory Capture," Quarterly Journal of Economics 106(4): 1089-1127.

Leonard, Bryan and Gary D. Libecap (2015) "Endogenous First-Possession Property Rights in Open Access Resources," Iowa Law Review, forthcoming.

Libecap, Gary D. (1978), "Economic Variables and the Development of the Law: The Case of Western Mineral Rights," Journal of Economic History 38 (2): 338-62. 
Libecap, Gary D. (2008), "Open-Access Losses and Delay in the Assignment of Property Rights.” Arizona Law Review 50 (Summer): 379-408.

Libecap, Gary D. (2009), “The Assignment of Property Rights on the Western Frontier: Lessons for Contemporary Environmental and Resource Policy," The Journal of Economic History 67(2): 257-91.

Libecap, Gary D. and Dean Lueck (2011), "The Demarcation of Land and the Role of Coordinating Property Institutions," Journal of Political Economy 119 (3): 426-467.

Libecap, Gary D. Dean Lueck, and Trevor O'Grady (2012), "Large Scale Institutional Changes: Land Demarcation within the British Empire," Journal of law and Economics 54 (4): S295-S327.

Libecap, Gary D. (2014) "Addressing Global Environmental Externalities: Transaction Costs Considerations," Journal of Economic Literature 52(2): 424-79.

Medema, Steven G. (2011), "A Case of Mistaken Identity: George Stigler, "The Problem of Social Cost," and the Coase Theorem," European Journal of Law and Economics 31: 1138.

Medema, Steven G. (2014), "The Curious Treatment of the Coase Theorem in the Environmental Economics Literature, 1960-1979," Review of Environmental Economics and Policy 8(1): 39-57.

Merrill, Thomas W. and Henry E. Smith (2010), Property, New York: Oxford University Press.

Newell, Richard G., James N. Sanchirico, Suzi Kerr (2005), "Fishing Quota Markets," Journal of Environmental Economics and Management 49: 437-62.

O’Grady, Trevor (2015), "Spatial Institutions in Urban Economies: How City Grids Affect Development," working paper Harvard University Economics Department.

Ostrom, Elinor (1990), Governing the Commons: The Evolution of Institutions for Collective Action, Cambridge University Press.

Peltzman, Sam (1976), “Toward a More General Theory of Regulation," Journal of Law and Economics 19(2): 211-240;

Pigou, A.C. (1932), Economics of Welfare, $4^{\text {th }}$ Edition, London: Macmillan.

Samuelson, Paul A. (1948), Foundations of Economic Analysis, Cambridge, MA: Harvard University Press.

Scitovsky, Tibor (1954), “Two Concepts of External Economies, “ Journal of Political Economy 
62(2):143-151.

Singh, Rajesh, Quinn Weninger, and Matthew Doyle (2006), "Fisheries Management with Stock Growth Uncertainty and Costly Capital Adjustment." Journal of Environmental Economics and Management. 52 (September): 582-99.

Stavins, Robert N. (1995), “Transaction Costs and Tradable Permits," Journal of Environmental Economics and Management 29: 133-48.

Stavins, Robert N. (2007), "Market-Based Environmental Policies: What Can We Learn from U.S. Experience (and Related Research)?” in Jody Freeman and Charles D. Kolstad, eds, Moving to Markets in Environmental Regulation: Lessons from Twenty Years of Experience, New York: Oxford University Press, 19-47.

Weitzman, Martin L. (1974), "Prices vs. Quantities," The Review of Economic Studies 41 (4): 477-91. 